\title{
SOME PROBLEMS OF MAINTENANCE AND REPAIR OF ANIMAL HUSBANDRY
}

\author{
НЕКОТОРЫЕ ПРОБЛЕМЫ РЕМОНТНО-ОБСЛУЖИВАЮЩЕЙ БАЗЫ \\ ЖИВОТНОВОДСТВА
}

\author{
L.I. Kovalev, Associate Professor ${ }^{1}$ \\ Л.И. Ковалёв, кандидат экономических наук, доцент
}

\author{
I.L. Kovalev, Researcher ${ }^{2}$ \\ И.Л. Ковалёв, научный сотрудник
}

\author{
${ }^{1}$ Belarusian State Agrarian Technical University \\ Белорусский государственный аграрный технический университет \\ Phone: +375 29 3915111, E-mail: olbosigor@mail.ru
}

\footnotetext{
${ }^{2}$ The Institute of System Research in Agro-industrial Complex of NAS of Belarus Институт системных исследований в АПК Национальной академии наук Беларуси Phone: +375 291266912
}

\begin{abstract}
The article raises a number of important issues and the current state of the material and the production base of technical service animal husbandry.

\section{АННОТАЦИЯ}

В статье поднят ряд важных вопросов и проблем нынешнего состояния материальнопроизводственной базы технического сервиса животноводства.
\end{abstract}

\section{KEY WORDS}

Animal husbandry; Specifications; Equipment; Technical service; Maintenance; Repair.

КЛЮЧЕВЫЕ СЛОВА

Животноводство; Нормативы; Оборудование; Технический сервис; Техническое обслуживание; Ремонт.

Начало нынешнего столетия отмечено весьма интенсивным ростом энерговооруженности животноводства, поступлением в сельское хозяйство более сложных, высокопроизводительных машин. Так, в настоящее время система машин для комплексной механизации животноводства содержит свыше 1050 наименований, или по сравнению с 1980 годом количество средств возросло в 1,6 раза. Но технический прогресс в сельском хозяйстве нельзя сводить только к наращиванию поставок новых и большей номенклатуры машин и оборудования. Неотъемлемая и активная часть этого прогресса состоит в умении правильно использовать технические средства. Чем совершеннее техника, тем грамотнее должно быть ее использование. Без этого трудно добиться роста производительности труда и снижения затрат на производство продукции в сельхозорганизациях.

В связи С ростом уровня механизации производственных процессов в животноводстве все более актуальной становится задача повышения уровня технического обслуживания и ремонта животноводческой техники. Поэтому технический сервис (ТС) занимает одно из ведущих мест в структуре подотраслей животноводства. Состояние его технической базы и эфрфективное фрунццинирование являются важными предпосылками экономического возрождения, роста производства и качества продукции на ближайшую и долгосрочную перспективу.

Для обеспечения постоянной работоспособности машин и оборудования в заданных режимах в середине восьмидесятых годов XX века в бывшем СССР были созданы станции технического обслуживания животноводческой техники (СТОЖ) 
практически в каждой райсельхозтехнике $и$ хорошо технически оснащены стационарным оборудованием и передвижными средствами. В Белоруссии были созданы СТОЖ во всех административных районах, из них свыше $50 \%$ построено по типовым проектам, 57 станций мощностью - 250,0 тыс. руб.(еще советских руб.), и 4 мощностью - 350,0 тыс. руб. в год. Следует отметить, что типовые станции были использованы на $65-70 \%$ от своей мощности.

Техническое обслуживание животноводческой техники осуществлялось хозяйствами и СТОЖ. В республике в основном была принята децентрализованная форма обслуживания, где ежесменное обслуживание осуществлялось силами хозяйства, а сложные операции периодического технического обслуживания и ремонт - силами и средствами СТОЖ по договорам с хозяйствами.

Объем работ, выполненный станциями СТОЖ в 1980 году, составил 20,3 млн. руб., соответственно в 1985 году 23,8 млн. руб., или сопоставимый объем работ в ценах 2010 года равен - 71,4 млрд. руб. Численность работающих в 1985 году составляла 3487 человек, в том числе рабочих 2775 человек. В этот период для выполнения работ по техническому обслуживанию и ремонту непосредственно на балансе районных СТОЖ находилось передвижных мастерских в количестве 811 единиц, в том числе МПР-4844 - 240 ед.; ММТОЖ -231 ед. и АЖМ - 340 ед. В республике функционировало 393 выездные бригады и задействована численность рабочих 2190 человек или $70 \%$ от общего количества.

После распада Советского Союза и отсутствия предложений СТОЖ на оказание услуг со стороны хозяйств, соответственно вышеприведенная форма обслуживания прекратила свои функции обслуживания техники. Практически обслуживание животноводческой техники проводилось силами хозяйств централизованным методом. Однако с обновлением в хозяйствах парка машин с автоматизированным управлением технологическими процессами, а также реконструкцией молочных фрерм и комплексов, возникла необходимость иметь производственную базу и высококвалифицированных специалистов для техобслуживания техники. Ввиду отсутствия в хозяйствах специалистов и производственной базы создается проблема в организации системы технического обслуживания в первую очередь при современном оснащении техникой молочных ферм и комплексов, поэтому созданы специализированные службы молокоперерабатывающими предприятиями по техническому обслуживанию и ремонту машин и оборудования молочных ферм. Создание специализированных служб при молокозаводах - это не только субъективная причина образования ниши по оказанию услуг на рынке агросервисного обслуживания животноводческой техники, но и необходимая сложившаяся, объективная закономерность поддержания технической готовности техники в целях увеличения объемов и качества производимой продукции.

В 24 районах республики обслуживанием доильного оборудования занимаются молочные заводы. Кроме того, в отдельных районах республики ведется обслуживание машин и оборудования доильных залов заводом «Промбурвод». Однако основной службой технического сервиса в республике являются станции СТОЖ.

В настоящее время в республике в 62 райагросервисах действуют станции технического обслуживания животноводческого оборудования, которые обслуживают около 12,0 тыс. ед. доильных и около 9,0 тысяч холодильных установок, поставленных в основном до 1996 года. Среднегодовой объем работ по ТО и ремонту доильного и холодильного оборудования за 2007-2009 годы составил в порядке 32,0 млрд. бел.руб. в ценах 2009 года. Наибольший прирост оказанных услуг наблюдается в Витебской 2,1 раза, Могилевской, Гомельской и Брестской областях соответственно 1,5 раза. Следует отметить, что во многих хозяйствах техническое обслуживание доильных залов силами агросервисов производится по разовым затратам, а не по нормативам затрат, которых практически нет для проведения взаиморасчетов за оказанные услуги. Хозяйствами не соблюдаются сроки замены сосковой резины, а также регламент по проведению техобслуживания, отсутствует нормативный запас материалов и запасных частей, моющих и дезинфицирующих средств. 
По обслуживанию импортного доильного оборудования в республике действуют два сервисных центра от фииры WESTFALIA Surge (в Минской и Гродненской областях), шесть передвижных сервисных пунктов от фрирмы Impulsa (в каждой области), 3 сервисных центра от ОАО «Гомельагрокомплект» (в Брестской, Минской и Гомельской областях).

Мировой опыт показывает, что сервисная служба с широкой сетью обслуживания является неотъемлемой частью технологической цепочки производства молока. Если в США, Канаде, Европе эта система четко налажена, то в Беларуси у многих сельскохозяйственных товаропроизводителей доильное оборудование не содержится в соответствующем техническом состоянии по многим причинам: отсутствие денежных средств на проведение техобслуживания, дефицит квалифицированных кадров для ежедневного ухода за оборудованием и прочее.

Проводимые исследования учеными Беларуси, России, США и других стран показали, что огромный материальный ущерб сельскохозяйственным предприятиям наносится эксплуатацией неисправного доильного оборудования. Так, количественная заболеваемость коров субклиническим маститом при неисправности доильной установки возрастает в 3-3,5 раза по сравнению с использованием исправного оборудования. По данным исследований в США экономические потери от маститов составляют в среднем около 117 долларов в год на одну корову. Из них на сокращение производства молока приходится около 65\%, при среднегодовом удое 4850-4900 кг на одну корову поражение маститом приводят к потерям 530-550 кг молока в год или 9$10 \%$ от годового производства. Наши расчеты показывают, что только от недобора молока хозяйства республики теряют около 320-340 млрд. рублей денежных средств ежегодно. Кроме того, возрастают расходы на ветеринарные услуги, лекарственные препараты, а также на ремонт стада из-за преждевременной выбраковки коров. На эти цели сельхозтоваропроизводителями израсходуется 60-65 млрд. рублей в год.

Следует также отметить, что примесь «маститного» молока в сборном молоке существенно влияет на качество производимых из него молочных продуктов, поэтому молочные заводы строго контролируют наличие в молоке ингибиторов роста молочных бактерий. По данным мясо-молочной промышленности Минсельхозпрода за 2009-2011 гг. у белорусских сельхозпредприятий было закуплено молока: сорта «экстра» - в среднем $12,5 \%$, высшего - $65 \%$, первого - $20 \%$, второго - 2,5\%.

Во времена Советского Союза закупка молока производилась только в основном по трем сортам (I сорт, II сорт и несортовое) в соответствии с действующим в тот период стандартом.

Опыт показывает, что благодаря отлаженной системе организации технического обслуживания и ремонта животноводческой техники агросервисными службами, колхозы и совхозы в 1984-1986 годах смогли довести показатель реализации по качеству молока I сортом свыше $85 \%$ в целом по стране, а несортовое молоко составляло всего около 2\%. В Белорусской ССР в указанные годы эти результаты были значительно выше (I сортом - 89\%, II сортом - 10\%, несортовое молоко составляло 1\%).

Проводимые исследования в 1980-1985 годах в разных регионах страны институтами ВНИИТИМЖ (г. Минск), ВНИЭТУСХ (г. Москва), ВИЭСХ (г. Москва), НИПТИМЭСХ Н.3. РСФСР (Ленинградская обл.), ВИИТиН (г. Томбов) и др. привели к однозначным выводам, что при несоблюдении регламента по проведению технического обслуживания и ремонта животноводческой техники снижается не только продуктивность животных, но и качество молока в 2-2,5 раза.

На основании анализа и исследований можно сделать вывод, что в современных условиях предприятия и организации, обслуживающие технику, разъединены между собой и в то же время не нацелены на снижение издержек и цен на сервисные услуги и повышение их качества. Действующие самостоятельно в административных районах ремонтные, монтажные, транспортные и другие предприятия разобщены, удалены от хозяйств на значительные расстояния и не имеют объективной ориентации о тенденциях развития служб технического сервиса. Основная же причина всех этих 
негативных явлений кроется в низкой платежеспособности товаропроизводителя, основного потребителя услуг службы технического сервиса. Невозможность приобретения им новых машин и оборудования, финансовая несостоятельность для оплаты услуг ремонтно-обслуживающих работ, выполняемых специализированными ремонтными предприятиями, вынуждает последних менять профиль своей деятельности, искать сфреры деятельности несвойственные основному своему предназначению. Слабой остается материально-техническая база технического сервиса непосредственных производителей животноводческой продукции, в которых производится до $70 . .75 \%$ общего объема работ по обслуживанию машин. Поэтому развитие материальной базы сервисных служб непосредственно у сельхозтоваропроизводителей различных фрорм собственности, на животноводческих фермах, комплексах имеет в настоящее время важнейшее значение для качественного обслуживания доильного и холодильного оборудования на фермах республики.

\section{БИБЛИОГРАФИЯ}

[1] Ковалёв, Л.И. Организационно-технологические основы технического обслуживания и ремонта машин в молочном скотоводстве / Л.И. Ковалёв. Минск: БГАТУ, 2012. - 224 с. ил.: - ISBN 978-985-519-530-7.

[2] Ковалёв, Л.И. Основы организации технического сервиса машин и оборудования животноводческих ферм и комплексов / Л.И. Ковалёв. - Минск: БГАТУ, 2011. - 136 с. ил.: - ISBN 978-985-519-434-8.

[3] Ковалёв Л.И., Ковалёв И.Л. Анализ состояния производственно-технической базы по обслуживанию и ремонту оборудования для животноводства // Главный зоотехник. - М.: Сельхозиздат.- 2012. - №12. - С.53-56.

[4] Ковалёв Л.И., Ковалёв И.Л. Анализ состояния производственно-технической базы по обслуживанию и ремонту машин, оборудования животноводства // Сельскохозяйственная техника: обслуживание и ремонт. - М.: Сельхозиздат.2012. - №11. - C.25-28. 